\title{
Preachiziții în învățarea scris-cititului la copiiii cu tulburări de invățare
}

\section{Ioana MATEI ${ }^{1}$}

\begin{abstract}
The first step in combating speech and language disorders, is checking if specific language development steps from infancy and toddlerhood have been done. Students from families with financial difficulties, that lack early childhood cognitive development, tend to be less skilled in reading or writing.

To avoid school dropout, we focused on identifying these issues when a child starts school and apply a ten week program.

This program has two components, one for teachers and the other for students. The main goal is to identify if certain early development milestones have been met, memory and atention development and phonology conscience. The program has proved it's eficacity even during the corona virus pandemic
\end{abstract}

Keywords: learning disabilities, early intervention, reading and writing

\section{Cadru teoretic}

Formarea deprinderilor de scris-citit constituie un obiectiv de o importanță deosebită în ciclul primar. A învăța pe micii școlari să citească și să scrie, în perspectiva evoluției lor intelectuale, înseamnă a-i învăța cum să învețe.

Se poate afirma că întreaga evoluție a elevilor, atât în școală, cât și în viață, depinde de măsura în care ei și-au însușit această deprindere, până la nivelul la care acesta să constituie un mijloc de autoinstruire.

Dobândirea competențelor de scris-citit va duce la ridicarea stimei de sine și - implicit - la evitarea abandonului şcolar.

Este dificil de făcut un demers de definire a conceptului de dificultăți de învățare, datorită complexității acestui fenomen, dar și datorită faptului că există perspective diferite, distincte, asupra acestuia, în funcție de paradigma psihologică în care se abordează acest tablou patologic.

"În prezent, domeniul tulburărilor de învățare se confruntă cu o absență a unor criterii unitare de diagnostic. Consensul nu este obținut nici măcar la nivel european. În plus, coexistența a două sisteme de clasificare importante (Manualul de diagnostic și statistică a tulburărilor mentale, ediția a 5-a, 2013, respectiv Clasificarea internațională a bolilor, 1993), dar care nu sunt concordante sub aspectul acestor criterii, face mai dificil demersul de diagnosticare și evaluare. De asemenea, în raport cu recunoașterea formală a acestor tulburări, tarile diferă sub aspectul impunerii unor standarde diagnostice și al varietății instrumentelor formale utilizate.(Roșan, David, 2017, p.9).

O dificultate de învățare se referă la o întârziere, o tulburare, o dezvoltare încetinită în plan emoțional sau comportamental, însă nu este rezultatul unei întârzieri mintale. Este semnalată astfel o necesitate care vine din domeniul practicii școlare efective.

O parte dintre tulburările limbajului scris-citit se datorează unei imaturităţi şcolare. Aceşti copii prezintă întârzieri în sfera proceselor cognitive de tip 
senzorial, care influențează negativ acuitatea perceptivă şi receptarea adecvată, în special a stimulilor vizuali şi auditivi. Uneori copiii nu pot percepe şi diferenţia la nivel de fonem - grafem și nu pot stabili legături între simbolurile grafice. Toate aceste aspecte ale imaturităţii şcolare (care intră fie în categoria tulburărilor de dezvoltare, fie în categoria tulburărilor de învăţare) fac să apară greutăți în însuşirea scriscititului, $\mathrm{cu}$ aspecte comune dislexieidisgrafiei, dar care în mare parte nu sunt dislexii-disgrafii. (Raus, Botezatu, Fărâmă, 2006)

Limbajul oral se dezvoltă pe baza preachizițiilor limbajului și a elementelor de psihomotricitate, iar limbajul oral stă la baza achiziției limbajului scris-citit. (Bodea-Hațegan, 2016).

Evaluarea preachizițiilor limbajului este un proces complex și amplu, dar care abordat terapeutic duce la dezvoltarea limbajului oral și implicit la facilitarea învațării limbajului scris-citit. Factorii de care depinde formarea deprinderilor de scris-citit poartă numele de preachiziții ale limbajului.

"Prima etapă în prevenirea apariției dificultăților de învățare este cea a structurării preachizițiilor. Preachizițiile asupra cărora țintesc demersurile de evaluare/prevenire sau intervenție sunt: orientare spațio-temporală, coordonarea motorie (coordonarea grupelor musculare de la nivelul aparatului fonoarticulator, coordonarea grupelor musculare de la nivelul mâinii, cordonare ochi-mână), procesare fonologică, lateralitate, procesare vizuală, motricitate generală/fină, schemă corporală” (Bodea-Hațegan, 2016).
Principala problemă a copiilor din mediile defavorizate este aceea că aceștia nu au participat (sau participă cu o frecvență redusă) la activitățile desfașurate în gradiniță. Astfel, învățătoarea - în clasa pregatitoare trebuie să pună un accent deosebit pe recuperarea și dezvoltarea preachizițiilor limbajului.

Focalizarea pe formarea și dezvoltarea aptitudinilor de școlaritate este deosebit de important, asigurând prevenția insuccesului școlar sau a eșecului școlar. (Burlea, 2007; Burlea, Milici, 2008)

Dificultățile de învațare afectează cel puțin 1 din 10 copii de școală. Definirea dificultăţilor de învăţare este necesară pentru a realiza o concordanță între nevoile reale ale practicii educaţionale şi conceptualizarea lor. Este acceptată existența unui număr mare de copii care prezintă dificultăţi de învățare, cel puţin o scurtă perioadă de timp din şcolaritatea lor. Practic, nu există copil care să nu întâmpine greutăţi măcar o dată în învățarea din şcoală. Pe de altă parte, sfera învățării umane este mult mai largă decât învățarea școlară. (BălașBaconschi, 2010)

\section{Descrierea studiului derulat și a rezultatelor obținute}

În acest scop, este important să identificăm nivelul preachizițiilor și nivelul de dezvoltare cognitivă a copiilor de clasa pregatitoare și clasa I din școala noastră, care are un specific aparte. $90 \%$ dintre copii proveniți din medii sociale defavorizate.

Obiectivele cercetării au fost: realizarea unui program de intervenție pentru prevenirea apariției și corectarea 
tulburărilor de scris-citit la școlarii mici; aplicarea programului unor grupuri de școlari proveniți din medii sociale defavorizate; monitorizarea însușirii preachizițiilor limbajului la copiii implicați; realizarea și aplicarea unor probe de evaluare în etapa inițială și cea finală a cercetării.

Cercetarea de față pornește de la două ipoteze:

- Participarea la un program de evaluare și intervenţie personalizat bazat pe structurarea preachizițiilor limbajului contribuie la învățarea mai eficientă a scris-cititului la școlarii mici cu tulburări/dificultăţi de învăţare proveniți din medii sociale defavorizate.

-Dobândirea competenţelor de scriscitit vor duce la ridicarea stimei de sine şi implicit la evitarea abandonului şcolar.

Pentru atingerea obiectivelor și verificarea ipotezelor mai sus enunțate, s-a apelat la evaluarea nivelului de preachiziții prin probe de evaluare și aplicarea timp de 10 săptămâni a unui program de intervenție.

Cercetarea de față s-a efectuat în cursul anului școlar 2019-2020 în cadrul Școlii Gimnaziale "Traian Dârjan", iar intervenția propriu-zisă a avut loc în perioada Septembrie 2019 - Iunie 2020.

S-au examinat un număr de 25 de copii, cu vârsta între 6-8 ani, în Școala Gimnazială "Traian Dârjan" Cluj-Napoca. Dintre aceștia 13 sunt fete și 12 sunt băieți. Criteriul selecției subiecților pentru cercetare a fost cel al vârstei. Pentru 13 elevi s-a aplicat programul de intervenție (elevii clasei $\mathrm{CP}$ A), iar 12 elevi au rămas grupul de control (elevii clasei CP B). Evaluarea s-a făcut individual în cabinetul logopedic, iar intervenția s-a făcut la clasă, în colaborare cu învațătorii de la clasă.

S-au aplicat probele la două clase pregătitoare. La clasa pregătitoare A s-a aplicat programul de intervenție timp de 10 săptămâni. Clasa pregătitoare B e grup de control.

În scopul elaborării cercetării s-au utilizat o serie de metode de investigare care au fost utile în aprofundarea temei propuse.

Astfel, pentru a duce la bun sfârşit cercetarea s-au folosit: observaţia, convorbirea, explicaţia, exerciţiul, studiul bibliografic, probă pentru cunoașterea vârstei psihologice a limbajului - Alice Descoeudres, Proba de evaluare a abilităților morfologice în limba română, Probă de evaluare - clasa pregătitoare.

Proba de evaluare a abilităților morfologice în limba română - PEAMLR realizată de Bodea-Hațegan (2014) este o probă adaptată după Test for Reception of Grammar - TROG. Proba permite stabilirea nivelului comprehensiunii verbale, cu focalizare asupra abilităților de receptare a categoriilor gramaticale. Proba constă în nouăzeci şi doi (92) de itemi, patru pentru fiecare dintre aspectele gramaticale abordate, fiecare item al probei este redat imagistic, iar sarcina copilului este aceea de a indica imaginea corespunzătoare itemului.

Probă pentru cunoașterea vârstei psihologice a limbajului - Alice Descoudres: Testul de stabilire a vârstei psihologice a limbajului adaptat după 
Alice Descoeudres este o probă care se poate aplica la copii de de la 2 ani până la vârsta de 7 ani. Această probă conține șapte subteste, care vizează dezvoltarea gândirii și a limbajului. (Vrășmaș, Oprea, 2003).

Probe de evaluare - clasa pregătitoare: Proba este creată pentru evaluarea preachizițiilor limbajului scris-citit.

S-a realizat un program marcat de o puternică trăsătură de aplicabilitate, datorită numărului mare de exerciții și fișe, care a devenit un instrument de lucru atât într-un program educativ aplicat la clasă pentru dobândirea și dezvoltarea preachizițiilor limbajului, cât și unul terapeutic-recuperator aplicat în cabinetul logopedic.

Programul a fost structurat pe 10 săptămâni. A fost aplicat la clasa pregătitoare $A$ de către învățătoare în colaborare cu profesorul logoped. Planul de intervenție este structurat pe 6 teme importante ale preachizițiilor scriscititului mai exact: schemă corporală, lateralitate, orientare spaţio-temporală, serialitate, conștiință fonologică, atenție și memorie.

Ghidul pentru învățători este completat cu un program de intervenție: 90 de fișe de lucru, destinate copiilor din clasa pregătitoare, grupate pe cele 6 teme (schemă corporală, lateralitate, orientare spațio-temporală, serialitate, conștiință fonologică, atenție și memorie structurate).

Rezultatele obținute de ambele grupe în evaluarea inițială sunt la același nivel, nu se observă diferențe semnificative între participanți. În următoarea etapă a cercetării, participanții din lotul experimental au fost incluși într-un program de intervenție terapeutică personalizat, în timp ce la lotul de control nu au fost aplicate nici un fel de programe personalizate.

Elevii din eșantionul de control au înregistrat un progres ușor faţă de perioada iniţială, datorat participării la activitățile clasei pregătitoare. Ei încă mai întâmpină dificultăţi semnificative. Au chiar și staționări sau un ușor regres, datorat absenteismului școlar, dar și perioadei de pandemie. Dupa cum arată și rezultatele din evaluarea inițială, dar și cele din evaluarea finală, pregătirea pentru începerea scris-cititului nu s-a realizat eficient.

Elevii din eșantionul experimental au înregistrat un progres semnificativ faţă de perioada iniţială, datorat participării la programul de intervenție. Aceasta se poate observa din studierea mediilor la probele inițiale și la cele finale.

În evaluarea inițială grupul experimental a obținut următoarele rezultate:

- la proba PEAMLR: o medie de 53 care corespunde centilului 5 / dificultate mintală ușoară / dificultăți de învățare conform etalonului orientativ,

- la proba Alice Descoudres: o medie a vârstei psihologice a limbajului de 4,73 (iar media vârstei reale fiind de $6,28)$,

- la proba de evaluare: 49, 15 corespunde calificativului Suficient, aproape de limita de jos.

În evaluarea finală, grupul experimental a obținut următoarele rezultate: 
- la proba PEAMLR: o medie de 73, care corespunde centilului $7 /$ valizi conform etalonului orientativ,

- la proba Alice Descoudres: o medie a vârstei psihologice a limbajului de 6 , 37 (iar media vârstei reale fiind de $6,28)$,

- la proba de evaluare: 65,69 corespunde calificativului Bine.

În evaluarea inițială, grupul de control a obținut următoarele rezultate:

- la proba PEAMLR: o medie de 56,8 care corespunde centilului 5 / dificultate mintală ușoară / dificultăti de învățare conform etalonului orientativ,

- la proba Alice Descoudres: o medie a vârstei psihologice a limbajului de 4,67 (iar media vârstei reale fiind de 6,27),

- la proba de evaluare: 45,15 corespunde calificativului Suficient, aproape de limita de jos.

În evaluarea finală, grupul de control a obținut următoarele rezultate:

- la proba PEAMLR: o medie de 58,5 care corespunde centilului $5 /$ dificultate mintală ușoară conform etalonului orientativ,

- la proba Alice Descoudres: o medie a vârstei psihologice a limbajului de 5,38, iar media vârstei reale fiind de 6,27 (aici s-a inregistrat chiar o scădere semnificativă datorată absenteismului școlar, dar si perioadei de pademie),

-la proba de evaluare: 47,7 corespunde calificativului Suficient, la limită.

Programul de intervenție și dezvoltare a peachizițiilor limbajului, atât pentru cadrele didactice, cât și pentru elevi, structurat pe 10 săptămani, a evidențiat ritmurile specifice de dezvoltare a copiilor, precum și viteza cu care se recuperează. Din analiza datelor rezultă că elevii din grupul experimental înregistrează medii semnificativ mai mari decât cei din grupul de control.

Figura 1- Rezultate obținute la proba PEAMLR - Grup experimental

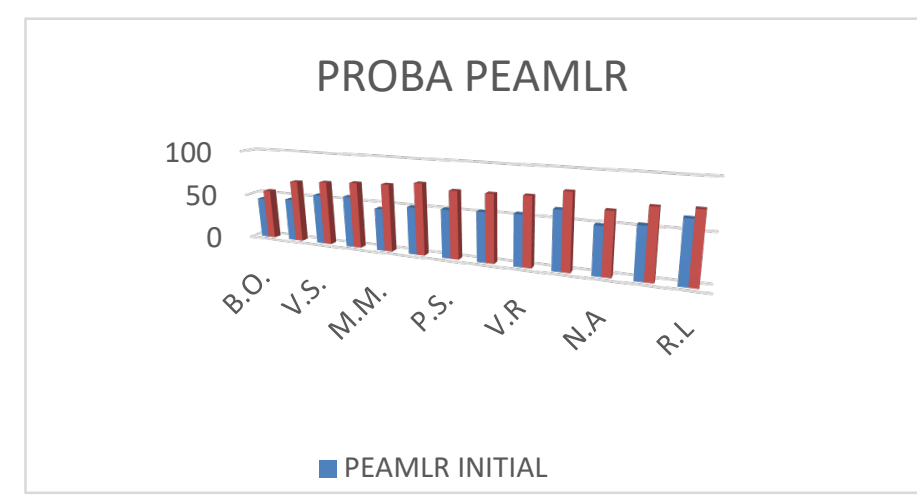

Figura 2 Rezultate obținite la proba PEAMLR - Grup control

Grup control PEAMLR

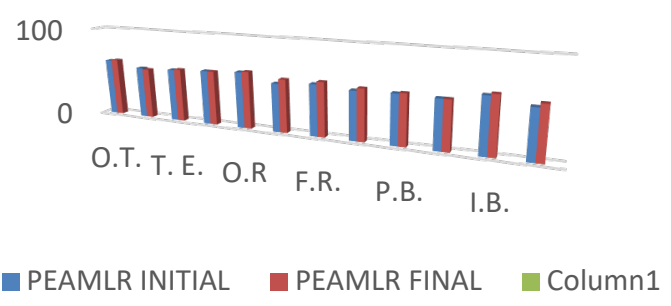

Elevii din grupul experimental au înregistrat un progres semificativ în ceea ce privește nivelul atins pentru proba PEAMLR. S-au dovedit a fi mult mai receptivi la asimilarea semnificaţiei noilor cuvinte şi la integrarea lor în enunțuri. Tot progres au înregistrat și elevii din grupul de control, însă majoritatea dintre ei încă mai întâmpină dificultăți în utilizarea noilor cuvinte în enunţuri. 
În evaluarea inițială elevii au întâmpinat dificultăți la nivelul următoarelor categorii morfologice: categorii morfemice care definesc verbul (mod, timp, diateză); prepoziții compuse; conjuncții coordonatoare; morfeme derivative; morfeme suprasegmentale; categoriile morfematice care asigură performanțe crescute (articol, gen, pronume; numeral cardinal; numeral ordinal; morfeme număr). Astfel, în cabinetul logopedic prin fișele personalizate am pus accent pe dezvoltarea și fixarea acestor categorii morfemice. Astfel, în evaluarea finală se observă o creștere semnificativă a rezultatelor.

Figura 3 Rezultate obținute la proba Alice Descoudres - Grup experimental

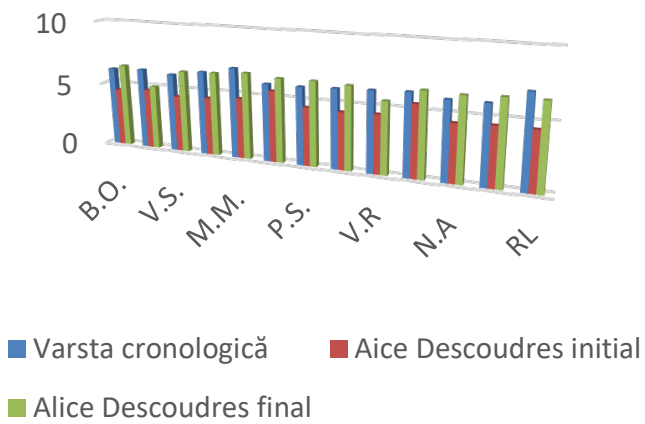

În cazul elevilor din grupul experimental, s-a constatat un progres semnificativ în atingerea subtestului 3, memorarea. Aceasta s-a datorat exercițiilor realizate în timpul programului, exerciții care au vizat antrenarea atenției și a memoriei de lucru. S-au realizat cu succes jocuri de atenție de tipul: "Jocul perechilor", "Jocul umbrelor", "Jocul diferențelor" și jocuri de memorie. S-a realizat un progres semnificativ și la subtestul 2, completarea lacunelor într-un text.
Figura 4 Rezultate obținute la proba Alice Descoudres - Grup control

\section{Grup de control-Proba Alice Descoudres}

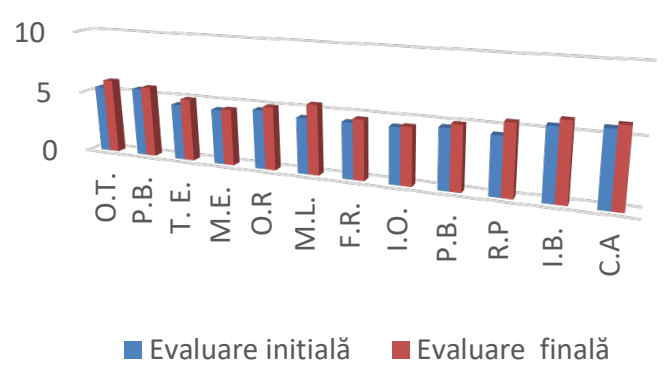

Dacă în evaluarea inițială majoritatea dădeau răspunsuri la întamplare, fără să înțeleagă aproape deloc textul, acum datorită programului de intervenție majoritatea reușesc să înțeleagă un text scurt. Jocurile din programul de interventie de tipul Băiatul / fetița spune..., exercițiile de diferențiere și succesiune, memorare a zilelor săptămânii: "Mergi în ritmul dat de mine!", "Baloanele cu zilele săptămânii”, precum și exercițiul-joc de asociere a momentelor zilei cu activităţile corespunzătoare ("Orarul în imagini") au ajutat foarte mult la atingerea acestui obiectiv.

Datorită exercițiilor din fișele de lucru, acum majoritatea cunosc toate culorile și cele primare și secundare și nu mai dau raspunsuri la întamplare. Toate acestea au dus la creșterea punctajului la aceasta probă și apropierea vârstei psihologice a limbajului de vârsta reală comparativ cu grupul de control unde acest lucru nu s-a realizat, ba chiar s-a înregistrat o ușoară scădere. 
Figura 5 Rezultate obținute la Proba de evaluare pentru clasa pregătitoare - Grup experimental

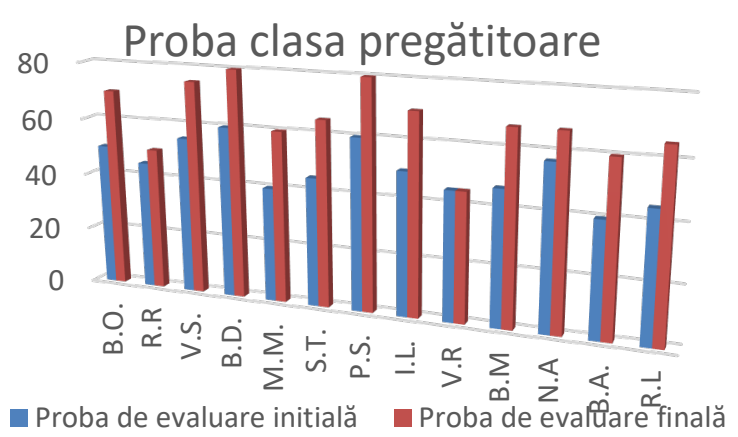

Figura.6 Rezultate obținute la Proba de evaluare pentru clasa pregătitoare - Grup de control

\section{Grup de control- Probă de evaluare}

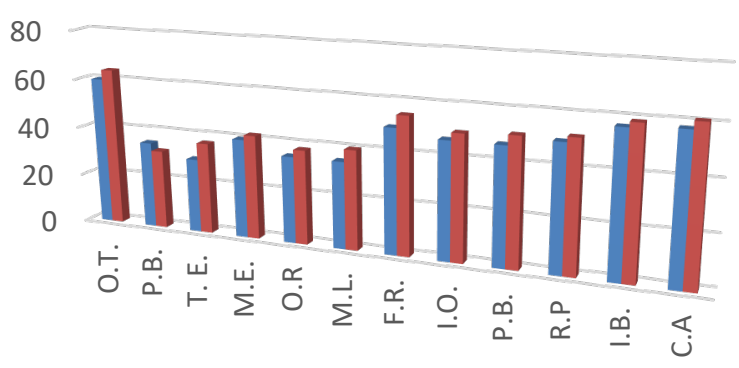

- Proba de evaluare initială @ Proba de evaluare fina

Elevii din grupul experimental au înregistrat un progres însemnat în atingerea (într-o proporţie mult mai mare) standardului privind formarea deprinderilor de exprimare orală. Se străduiesc să răspundă corect şi în propoziţie la întrebările care le sunt adresate, identifică sinonimele şi antonimele cuvintelor date, într-o proporţie mult mai mare. Elevii din grupul experimental formulează clar şi concis întrebări şi utilizează formulele de politețe în comunicarea cu ceilalți. Unii elevi mai întâmpină dificultăți în formularea de mesaje din cel puţin trei propoziţii aşezate într-o ordine logică.
Majoritatea operează cu noțiuni de relații spațiale, reușesc să se orienteze temporal, operează cu noțiuni legate de timp și au început să dezvolte structuri spațio-temporale. $\mathrm{Nu}$ sunt conștienți încă de rimă, nu știu un lucru: cuvintele pot rima. În schimb, nu întâmpină probleme cu exercițiile de ritm și preferă exercițiile de serialitate. Cele mai mari progrese s-au realizat la nivelul conștiinței fonologice. În evaluarea inițială nu aveau nici o noțiune legată de propoziție, cuvânt, silabă. Jocuri și exerciții din programul terapeutic:

-repetarea de cuvinte necunoscute din ce în ce mai complicate din punct de vedere fonologic;

- manipularea silabelor la începutul sau la sfârşitul cuvintelor;

-localizarea, recunoașterea silabei dintr-un cuvânt și localizarea poziției sale;

-identificarea celor două silabe dintrun cuvânt, substituirea silabei finale cu cea iniţială şi invers;

- exerciţii ce urmăresc aceleaşi obiective ca în etapa silabelor: localizarea, izolarea, identificarea intrusului, eliminarea sau adăugarea sunetelor, memorarea după auz a unor cuvinte şi propoziţii menţionate pentru sunetul vizat.

Aceste jocuri și exerciții din programul terapeutic au dus la obținerea unui punctaj ridicat de către majoritatea elevilor în etapa de evaluare finală. Acum sunt capabili să facă legături între ce aud și ce se scrie, încep să vadă corespondența dintre desfășurarea în timp și spațiu a scis-cititului, să cunoască codul alfabetic. 
În cazul elevilor din grupul de control, progresul înregistrat a fost mai mic. Problemele pe care le întâmpină se referă la despărțirea cuvintelor în silabe și la identificarea sunetelor în cuvânt. Dificultăți întâmpină și la identificarea proprietăților și la aranjarea imaginilor în succesiune, iar vocabularul rămâne sărac. Astfel, în analiza comparativă între procentajul elevilor din grupul experimental și cel de control, se observă diferențe majore în ceea ce privește atingerea în totalitate a obiectivelor de performanță propuse. În activităţile de învăţare, elevii au fost încurajaţi în permanență să se manifeste, să-şi exprime ideile, să-şi asume roluri şi responsabilităţi.

\section{Concluzii}

Performanțele în învățarea preachizițiilor limbajului atinse de elevii grupului experimental nu sunt percepute doar de către adulţi / cadre didactice. Ei înșiși percep aceste performanțe şi se responsabilizează în rezolvarea sarcinilor de lucru. De asemenea, ei înţeleg și obs ervă că implicarea lor este importantă. Ei manifestă dorinţa de a rezolva cât mai des fișele de lucru puse la dispoziția lor permanent, pentru a se face vizibili în rândul colegilor.

Din analiza datelor obținute de către cele două grupe de participanți, concluzionăm că preachizițiile limbajului deficitare sau nefuncționale pot duce la TSI, dar intervenind din timp asupra lor, stimulându-le dezvoltarea, ajungem la îmbunătățirea performanțelor școlare ale elevilor. Considerăm că evaluarea timpurie a preachizițiilor limbajului la începutul clasei pregătitoare ar putea fi de mare folos în identificarea și diagnosticarea precoce a elevilor expuși riscului de a dezvolta tulburări specifice de învățare.

Recomandăm implementarea unor programe de depistări precoce a preachizițiilor limbajului în scop preventive din clasa pregătitoare, utilizarea probelor de evaluare selectate în cercetare în evaluarea elevilor aflați în clasa pregătitoare din ciclul primar, iar rezultatele obținute pot fi urmărite longitudinal în viitor la clasele primare. Pe baza evaluării cu probele aplicate în cercetare, se pot elabora proiecte recuperatorii și educative speciale $\mathrm{cu}$ scopul de-a preveni instalarea TSI și a asigura succesul școlar al copiilor.

\section{Bibliografie}

Bălaș-Baconschi, C. (2010). Psihopedagogia copiilor cu dificultăți de învățare, suport de curs universitar de la Facultatea de Psihologie și Științe ale Educației, Cluj-Napoca: UBB.

Bodea Haţegan, C. (2016). Logopedia. Terapia tulburarilor de limbaj. Structuri deschise, Bucureșt: Editura Trei.

Bodea Hațegan, C. (2014). Abordări terapeutice ale limbajului. Perspective actuale, vol. I , ClujNapoca: Presa Universitară Clujeană.

Burlea G. (2007). Tulburarile limbajului scris-citit, Iași: Editura Polirom.

Burlea, G., Milici, R. C. (2008). Exerciții pentru formarea și dezvoltarea aptitudinilor de școlaritate, Iași: Editura Polirom.

Raus G., Botezatu V., Fărâmă M. (2006). Formarea comportamentului lexic şi 
grafic la copilul cu dificultăți de învăţare, Iași, in Academia Edu, retrived from https://www.academia.edu/31051760/ Carte Comportamentul Lexic Grafic in 20.03.2021

David C., Roșan A. ( 2017). Repere diagnostice bazate pe dovezi științifice în tulburările specifice de învățare, Cluj-Napoca: , Editura Argonaut/ Limes.

Vrășmaș, E., Oprea, V. (2003). Set de instrumente, probe şi teste pentru evaluarea educaţională a copiilor cu dizabilităti, București: Editura Mar Link

1 Prof. logoped CJRAE Cluj - Școala

"Traian Dârjan" Cluj-Napoca

E-mail: ioanamatei8o@yahoo.com 